\title{
Secondary oxalate nephropathy in an athletic woman with a duplex collecting system and ureteral fibrosis
}

\author{
Albert Bui (1), ${ }^{1}$ Cherise Cortese, ${ }^{2}$ Ivan E Porter ${ }^{3}$
}

'Department of Internal Medicine, Mayo Clinic Florida, Jacksonville, Florida, USA 2Department of Pathology, Mayo Clinic Florida, Jacksonville, Florida, USA

${ }^{3}$ Department of Nephrology and Hypertension, Mayo Clinic Florida, Jacksonville, Florida, USA

\section{Correspondence to \\ Dr Albert Bui;}

bui.albert@mayo.edu

Accepted 16 December 2021

\section{DESCRIPTION}

A 78-year-old woman athlete presented with malaise and right flank pain. Her medical history was significant for well-controlled hypertension, a duplex collecting system (complete ureteral duplication on the right kidney and partial duplication down to just above the ureterovesical junction on the left kidney), ureteral strictures from prior radiation for uterine cancer, total hysterectomy, right-sided hydronephrosis and recurrent bilateral nephrolithiasis. She required numerous laser lithotripsies and ureteral stents. At presentation, vitals were unremarkable. Notable laboratory values included: haemoglobin $7.8 \mathrm{~g} / \mathrm{dL}(11.6-15.0 \mathrm{~g} / \mathrm{dL})$, bicarbonate $11 \mathrm{mmol} / \mathrm{L}$ (22-29 mmol/L), phosphorus $6.4 \mathrm{mg}$ dL $(2.5-4.5 \mathrm{mg} / \mathrm{dL})$, blood urea nitrogen $75 \mathrm{mg} /$ $\mathrm{dL}(6-21 \mathrm{mg} / \mathrm{dL})$, serum creatinine $(\mathrm{sCr}) 4.27 \mathrm{mg}$ $\mathrm{dL}$ (reference range: $0.59-1.04 \mathrm{mg} / \mathrm{dL}$ ) and estimated glomerular filtration rate (eGFR) $<15 \mathrm{~mL} /$

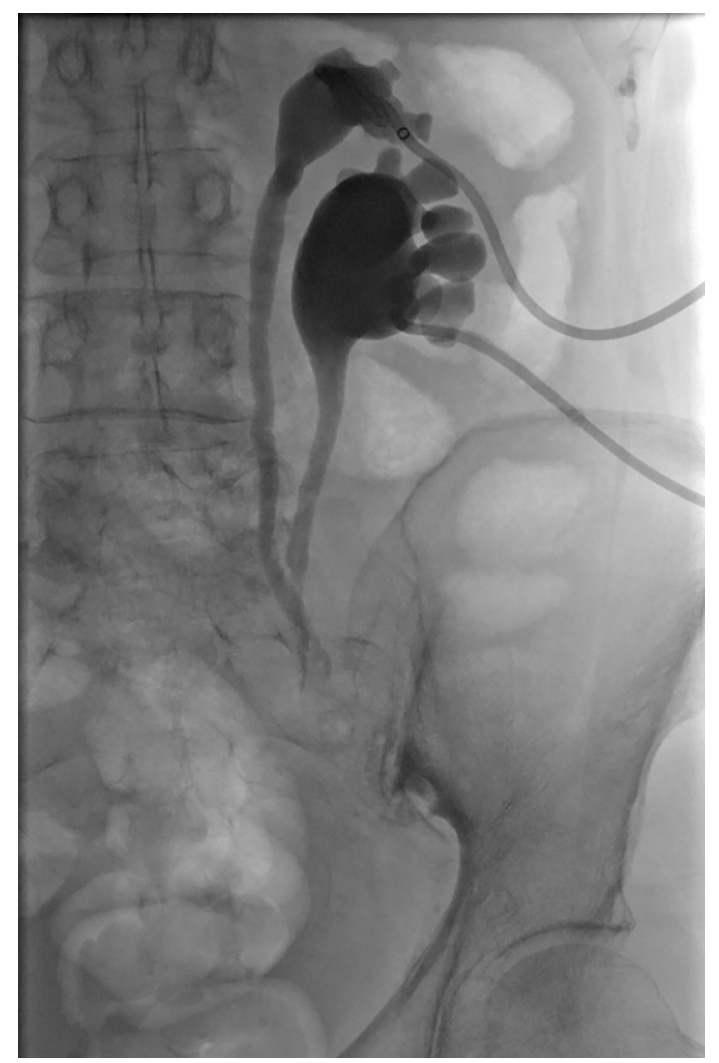

Limited 2021. No commercial re-use. See rights and permissions. Published by BMJ.

To cite: Bui A, Cortese C,
Porter IE. BMJ Case
Rep 2021;14:e246745.
doi:10.1136/bcr-2021-
246745

Figure 1 Nephrostogram; patient in prone position: right upper moiety demonstrates long segment of stenosis in the distal third of the ureter with sluggish clearance of contrast. Right lower pole moiety demonstrates obstruction of the ureter at the level of the renal pelvis without clearance of contrast.

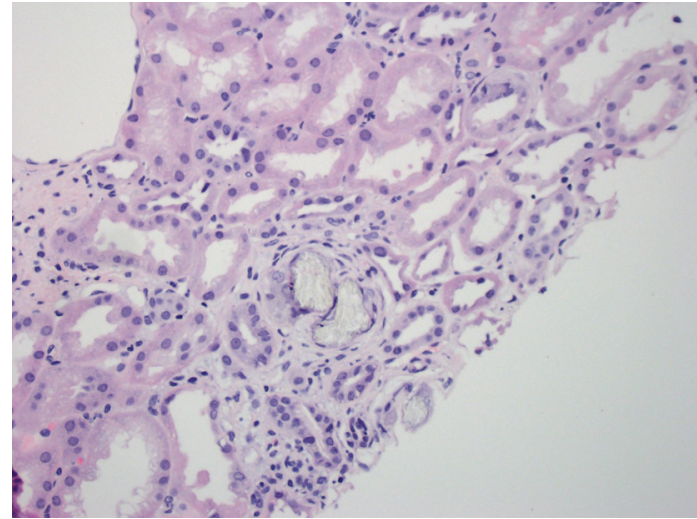

Figure 2 Light microscopy-H\&E stain $200 x$ —calcium oxalate crystals within the tubular lumen of the kidney. The crystals are clear and have a fan-shaped appearance. There is mild tubular atrophy and interstitial fibrosis $(5 \%$ of the parenchyma). There is mild arteriolar hyalinisation.

$\min /$ BSA. There was no leucocytosis. The patient's baseline $\mathrm{sCr}$ was $1.9 \mathrm{mg} / \mathrm{dL}$ before 1 month. The urology service performed a cystoscopy with bilateral retrograde pyelogram, which identified severe ureteral strictures involving the mid to distal ureters of both upper and lower pole moieties of the right kidney. There was hydronephrosis in the respective areas. Purulent and cloudy urine was visualised. Unfortunately, there was fibrosis-associated extrinsic compression of prior stents that required a right ureteral dilation. Additionally, two percutaneous nephrostomy tubes were placed in both moieties of the right kidney (figure 1). The left kidney contained several nonobstructive stones in bilateral pole moieties. It appeared grossly normal in size and contour. Due to a rapid decline in eGFR, the nephrology department was consulted, who pursued with a kidney biopsy. The procedure was performed on the left kidney to evaluate for other causes of medical renal disease. There was no evidence of primary glomerular disease via light microscopy, electron microscopy and immunofluorescence. However, eight of the sixteen sampled glomeruli were globally sclerosed. There were abundant calcium oxalate crystals in the tubules with mild tubular atrophy and interstitial fibrosis (5\% of the renal parenchyma) (figure 2). Fortunately, with urologic interventions and dietary education, the patient's sCr improved to $2.35 \mathrm{mg} / \mathrm{dL}$ with eGFR of $15-20 \mathrm{~mL} / \mathrm{min} / \mathrm{BSA}$. Postoperative antibiotics were not needed, as the patient's clinical status improved after fixing the urologic obstruction. The patient is currently receiving nephrostomy tube exchanges every 6-12 weeks. 
Secondary oxalate nephropathy can lead to acute kidney injury and chronic kidney disease. ${ }^{1}$ Our patient was predisposed to oxalate nephropathy and nephrolithiasis due to urologic obstruction. We suspect that her tortuous and fibrotic ureters from a duplex collecting system and prior radiation increased stagnant and supersaturated urine, which fostered crystalluria. ${ }^{2-7}$ Decreases in eGFR from obstruction increase time of interaction between the crystals and renal parenchyma. ${ }^{6-8}$ Microscopic crystals activate the NLRP3 inflammasome with subsequent generation of reactive oxygen species, tubular epithelial cell necroptosis and interstitial fibrosis. Damaged renal tubules serve as niduses for further crystallisation and stone formation. ${ }^{5}{ }^{6}$ Whereas secondary oxalate nephropathy is mostly caused by excessive dietary oxalate intake, dehydration and intestinal malabsorption, it is important to consider urologic obstruction and anatomical anomalies of the collecting system as potentiating factors. ${ }^{9-11}$

\section{Learning points}

- Oxalate nephropathy typically presents as acute on chronic kidney injury or acute kidney injury.

- Common precipitating factors of secondary oxalate nephropathy include increased intake of oxalate precursors, intestinal malabsorption, and inadequate hydration. Obstructive uropathy in the setting of a duplex collecting system and ureteral fibrosis can also predispose a patient to this condition.

Contributors IEP conceived the presented idea and conducted the study. $A B, C C$ and IEP collected and interpreted the data. AB wrote the manuscript in consultation with CC and IEP.
Funding The authors have not declared a specific grant for this research from any funding agency in the public, commercial or not-for-profit sectors.

Competing interests None declared.

Patient consent for publication Consent obtained directly from patient(s)

Provenance and peer review Not commissioned; externally peer reviewed.

Case reports provide a valuable learning resource for the scientific community and can indicate areas of interest for future research. They should not be used in isolation to guide treatment choices or public health policy.

\section{ORCID iD}

Albert Bui http://orcid.org/0000-0002-2927-7885

\section{REFERENCES}

1 Buysschaert B, Aydin S, Morelle J, et al. Etiologies, clinical features, and outcome of oxalate nephropathy. Kidney Int Rep 2020;5:1503-9.

2 Patel S, Abimbola O, Roy OP. Tortuous duplicated collecting system complicated by ureterovesical junction compression. Curr Urol 2020;14:50-3.

3 Başdaş C, Çelebi S, Özaydın S, et al. Unusual presentation of duplex kidneys: ureteropelvic junction obstruction. Adv Urol 2016;2016:7960794.

4 Bruno D, Delvecchio FC, Preminger GM. Successful management of lower-pole moiety ureteropelvic junction obstruction in a partially duplicated collecting system using minimally invasive retrograde endoscopic techniques. J Endourol 2000;14:727-30.

5 Mulay SR, Anders H-J. Crystal nephropathies: mechanisms of crystal-induced kidney injury. Nat Rev Nephrol 2017;13:226-40.

6 Mulay SR, Shi C, Ma X, et al. Novel insights into crystal-induced kidney injury. Kidney Dis 2018:4:49-57.

7 Alelign T, Petros B. Kidney stone disease: an update on current concepts. Adv Urol 2018;2018:1-12.

8 Dickson FJ, Sayer JA. Nephrocalcinosis: a review of monogenic causes and insights they provide into this heterogeneous condition. Int J Mo/ Sci 2020;21:369.

9 Geraghty R, Wood K, Sayer JA. Calcium oxalate crystal deposition in the kidney: identification, causes and consequences. Urolithiasis 2020;48:377-84.

10 Lumlertgul N, Siribamrungwong M, Jaber BL, et al. Secondary Oxalate Nephropathy: a systematic review. Kidney Int Rep 2018;3:1363-72.

11 Chen F. Genetic and developmental basis for urinary tract obstruction. Pediatr Nephro 2009;24:1621-32.

Copyright 2021 BMJ Publishing Group. All rights reserved. For permission to reuse any of this content visit

https://www.bmj.com/company/products-services/rights-and-licensing/permissions/

BMJ Case Report Fellows may re-use this article for personal use and teaching without any further permission.

Become a Fellow of BMJ Case Reports today and you can:

- Submit as many cases as you like

- Enjoy fast sympathetic peer review and rapid publication of accepted articles

- Access all the published articles

- Re-use any of the published material for personal use and teaching without further permission

Customer Service

If you have any further queries about your subscription, please contact our customer services team on +44 (0) 2071111105 or via email at support@bmj.com.

Visit casereports.bmj.com for more articles like this and to become a Fellow 